\title{
PENILAIAN KINERJA SOSIAL BERBASIS MAQASID SYARIAH PADA BANK UMUM SYARIAH HASIL KONVERSI DI INDONESIA
}

\author{
Siti Amaroh \\ Institut Agama Islam Negeri Kudus, Kudus \\ $\bowtie$ sitiamaroh@stainkudus.ac.id
}

\begin{abstract}
This paper aims to evaluate the social performance based on maqasid shariah of Islamic banks from conversion mode in Indonesia during the period 20142017. The data was obtained from Islamic banks' annual report that was validated by Bank Indonesia and Financial Services Authority. Maqasid shariah model in this study was developed by Abdul Majid Najjar with used 4 objectives and 8 dimensions and then referred by some researchers with some elements and measurements. This research is using 23 elements and derived into 19 ratios and 46 statements to determine scores of each objectives. The result showed several findings. Bank Panin Syariah achieved the highest scores of safeguarding human value (1st objective) during the period 2015-2017. Bank Central Asia Syariah reached the highest scores of safageuarding human self (2nd objective) during the period 2015-2017. Bank Mega Syariah Indonesia attained the highest scores of safeguarding for society (3rd objective) during the period 2014-2017. Bank Syariah Mandiri gained the highest score of safeguarding physical environment (4th objective) for the period 2014, 2016, and 2017. The highest total score for the overall objective is achieved by Bank Mega Syariah Indonesia during the period 2015-2017.
\end{abstract}

Keywords $\quad$ : Social Performance, Maqasid Shariah, Islamic Bank.

\section{LATAR BELAKANG}

Bank syariah dikembangkan dalam rangka mewujudkan kesejahteraan sosial ekonomi (Aliyu, 2014). Tujuan tersebut sejalan dengan tujuan Islam dalam merealisasikan keadilan bagi manusia yang dicapai dengan seperangkat nilai-nilai moralitas yang diterima oleh setiap orang dan diyakini dengan sepenuh hati (Chapra, 2009). Indikator keadilan dan kesejahteraan dapat dinilai melalui kontribusi bank syariah dalam menciptakan kesejahteraan sosial, partisipasi aktif bank syariah dalam pengentasan kemiskinan, dan edukasi tentang nilai-nilai Islam sebagai pandangan kehidupan sosial dan ekonomi terhadap masyarakat.

Tujuan utama lembaga keuangan Islam bukanlah untuk menghasilan laba (profitmaking), tetapi lebih kepada pemberian dukungan terhadap pengembangan kehidupan sosial dan penghapusan kemiskinan (Dusuki, 2008). Pencapaiannya tidak dapat dibatasi pada kegiatan amal seperti zakat, infaq, shadaqah, dan qardul hasan saja tetapi melibatkan mekanisme sosial yang terintegrasi dengan operasional bank. Bank syariah dinyatakan telah memenuhi tujuan syariah jika telah mampu menciptakan kesejahteraan dan kemaslahatan dalam masyarakat melalui produk-produknya baik 
itu pada produk dengan akad mudharabah, musyarakah, murabahah, ijarah, salam, maupun istishna.

Indonesia sebagaimana negara lain di dunia, beroperasi pada sistem perbankan ganda (dual banking system) dimana bank konvensional dan bank syariah beroperasi saling berdampingan. Sampai dengan 2017, sebanyak 13 Bank Umum Syariah (BUS), 24 Unit Usaha Syariah (UUS), dan 155 Bank Pembiayaan Rakyat Syariah (BPRS) telah berkembang di Indonesia.

Pendirian Bank Umum Syariah (BUS) dapat dilakukan melalui beberapa metode, antara lain: (1) berdasarkan Peraturan Bank Indonesia Nomor: 11/03/PBI/2009 tentang bank yang sejak awal didirikan sebagai BUS seperti Bank Muamalat Indonesia; (2) berdasarkan Peraturan Bank Indonesia Nomor: 11/15/PBI/2009 tentang BUS yang didirikan dari hasil konversi sebagaimana dilakukan oleh Bank Syariah Mandiri, Bank Mega Syariah Indonesia, Bank Panin Syariah, Bank BCA Syariah, dan Bank Victoria Syariah; (3) berdasarkan Peraturan Bank Indonesia Nomor: 11/10/PBI/2009 tentang pemisahan (spin off) Unit Usaha Syariah (UUS) menjadi BUS, contoh BNI Syariah dan Bank Jabar Syariah; dan (4) berdasarkan Peraturan Bank Indonesia Nomor: 11/03/PBI/2009 tentang pendirian bank syariah dengan cara konversi sekaligus spin off seperti pada Bank BRI Syariah dan Bank Bukopin Syariah.

Kinerja bank syariah merupakan salah satu tolok ukur pertumbuhan dan pijakan bagi langkah strategis pengembangan bank selanjutnya. Beberapa metode penilaian kinerja digunakan untuk mengevaluasi kinerja dan pencapaian-pencapaian lain bank syariah yang diformulasikan berdasarkan standar tertentu. Manfaat penilaian kinerja adalah untuk memudahkan internal bank dan stakeholder seperti pemerintah dalam rangka menyusun regulasi dan melakukan tindakan pengawasan.

Metode penilaian kinerja dan kesehatan bank yang selama ini digunakan antara lain metode CAMEL dan CAMELS. Metode CAMEL menilai kinerja bank baik bank syariah maupun bank konvensional berdasarkan beberapa ukuran yaitu Rasio Kecukupan Modal (Capital Adequacy Ratio), Kualitas Asset (Asset Quality), Manajemen Risiko (Risk Management), Pendapatan (Earning), dan Likuiditas (Liquidity). Sedangkan metode CAMELS pada prinsipnya menggunakan ukuran yang sama dengan metode CAMEL namun dengan menambahkan ukuran sensitifitas pasar terhadap risiko (Market Sensitvity to Risk). Kedua metode mengkategorikan kondisi bank dari sangat sehat hingga tidak sehat. Namun demikian metode penilaian ini masih dianggap belum sepenuhnya dapat merepresentasikan tujuan (maqasid) dari berdirinya bank syariah karena hanya menekankan pada aspek keuangan saja.

Tanggung jawab sosial menjadi identitas penting bagi bank syariah untuk mewujudkan perspektif maqasid syariah, karena sesuai konsepsi Islam peran ini tidak sekedar memenuhi harapan publik tetapi sebagai bentuk ketakwaan (Siwar dan Hossain, 2009). Asutay dan Harningtyas (2015) merumuskan pengukuran kinerja sosial dengan menggunakan konsep maqasid syariah menurut kerangka Abdel Majdi Najjar. Model ini merumuskan tujuan syariah kedalam empat tujuan penting. Berdasarkan pertimbangan tersebut maka penelitian ini akan menilai kinerja sosial berbasis maqasid syariah pada bank syariah hasil konversi di Indonesia.

\section{TEORI DAN METODE}

Syariah didesain pada basis kepentingan umat manusia (masalih al-'ibad) dan tujuan kemanusiaan (maslahah) sehingga berbagai dimensi untuk menyeimbangkan kehidupan manusia sebagai individu dan sosial dapat direalisasikan (laldin dan 
Furqani, 2013). Oleh karena itu, maqasid mencakup seluruh dimensi mikro dan makro dalam kehidupan individu dan masyarakat.

Maqasid syariah diartikan sebagai cita-cita dan tujuan syariah. Oleh karena itu maqasid syariah mencakup seluruh cita-cita dan tujuan syariah yang didalamnya terdapat standar, kriteria, nilai-nilai, dan panduan yang berasal dari Wahyu untuk diaplikasikan dalam memecahkan masalah umat manusia dan juga sebagai petunjuk dalam hidup (Laldin and Furqani, 2013).

Khusus pada keuangan dan ekonomi Islam, maqasid syariah merujuk pada keseluruhan tujuan dan maksud dalam transaksi dan kegiatan keuangan dan mencakup: Pertama, sirkulasi kekayaan. Sirkulasi kekayaan mencakup seluruh proses yang berhubungan dengan bagaimana mendapatkan kekayaan, konsumsi, dan distribusi. Kedua, praktik keuangan yang transparan dan adil. Prinsip ini memfasilitasi realisasi maslahah dan meminimalisir kesulitan dan kerugian dalam transaksi keuangan. Ketiga, keadilan pada dimensi mikro dan makro. Tujuan sirkulasi kekayaan berhubungan dengan tujuan makro syariah, sedangkan tujuan keadilan dan transparansi berkaitan dengan tujuan dimensi mikro dalam instrumen dan mekanisme transaksional.

Asy-Syatibi mengelompokkan maslahat kedalam tiga kelompok yaitu kebutuhan (daruriyyat), pelengkap (hajiyāt), dan perhiasan (tahsiniyāt) (Mohammed et al., 2015). Kebutuhan adalah elemen-elemen yang jika tidak diimbangi oleh sistem nasional akan mengakibatkan kekacauan. Kebutuhan ini terdiri dari lima elemen penting (aldarūriyat al-khams) antara lain agama (al-din), jiwa (al-nafs), intelektualitas (al-'aql), keturunan (al-nasl), dan harta (al-māl). Pelengkap merupakan elemen yang memfasilitasi kehidupan manusia. Sedangkan perhiasan sebagai hal-hal yang berkaitan dengan moral dan etika.

Maqasid syariah juga menjelaskan apa yang disebut dengan "wisdom behind rulings" seperti munculnya peningkatan kohesi sosial pada kegiatan sosial yang menciptakan hubungan sosial yang baik dan menciptakan perdamaian (Hurayra, 2015). Demikian pula maqasid syariah pada lembaga keuangan tidak semata-mata menekankan pada transaksi keuangan saja, tetapi mencakup seluruh aspek transaksi keuangan dan kehidupan manusia secara umum (Elahi, 2010). Aspek tersebut melibatkan banyak kegiatan seperti perdagangan, profit making, pengeluaran, dan kegiatan konsumsi. Menurut Mohammed et al. (2015) pengukuran kinerja perbankan syariah berbasis maqasid syariah memiliki tujuan yang luas yang disebut dengan tahdhib annafs (pendidikan dan disiplin individu), adl (keadilan), dan maslahah (kepentingan publik).

Menurut Abu Bakar dan Md Yusof (2015), tanggung jawab sosial dilaksanakan untuk tiga tujuan, yaitu: (1) untuk memenuhi kewajiban religious (religious obligation) sebagai entitas bisnis Islam; (2) untuk meningkatkan kesejahteraaan seluruh stakeholder seperti karyawan, pemilik modal, deposan, customer, masyarakat, dan juga lingkungan; dan (3) untuk meningkatkan reputasi atau citra bank syariah sebagai bank yang bertanggung jawab terhadap keberlangsungan (sustainability) bisnisnya.

Para ilmuwan muslim mulai merumuskan berbagai pengukuran yang dinilai rasional untuk mempermudah para praktisi perbankan syariah dalam menentukan standar-standar kinerja bank syariah. Konsep tersebut kemudian diderivasi kedalam dimensi, elemen, dan rasio sebagai variabel penjelas yang eksplisit.

Maqasid syariah menurut konsep Abdel Majid Najjar meliputi empat tujuan antara lain perlidungan terhadap nilai-nilai kehidupan manusia, perlidungan terhadap diri manusia, perlindungan terhadap masyarakat, dan perlindungan terhadap 
lingkungan fisik (Asutay dan Harningtyas, 2015). Perlindungan terhadap nilai-nilai kehidupan manusia (safeguarding human life value) meliputi loyalitas/keyakinan (faith) dan hak serta kepentingan stakeholder (rights and stakeholding), perlindungan terhadap diri manusia (safeguarding human self) mencakup diri individu (self) dan intelektualitas (intellectual), perlindungan terhadap masyarakat (safeguarding for society) terdiri dari keturunan (posterity) dan kekayaan (wealth), dan perlindungan terhadap lingkungan fisik (safeguarding physical environment) ditujukan bagi masyarakat (society) dan ekologi (ecology).

Model empat tujuan mencakup corporate governance yang menegaskan peran Dewan Pengawas Syariah (DPS) sebagai pihak yang ikut berperan dalam menetapkan legalisasi produk bank syariah. Dewan Pengawas Syariah memiliki peran penting dan strategis dalam penerapan prinsip syariah.. Selain itu DPS bertanggung jawab dan memastikan bahwa semua produk dan prosedur bank syariah telah sesuai dengan prinsip syariah. Kelebihan maqasid syariah 4 tujuan terletak pada cita-cita, komitmen, dan realiasi tanggung jawab sosial pada beberapa dimensi yang membentuk keseimbangan.

Gambar 1

Konsep Maqasid syariah menurut Abdel Majid Najjar

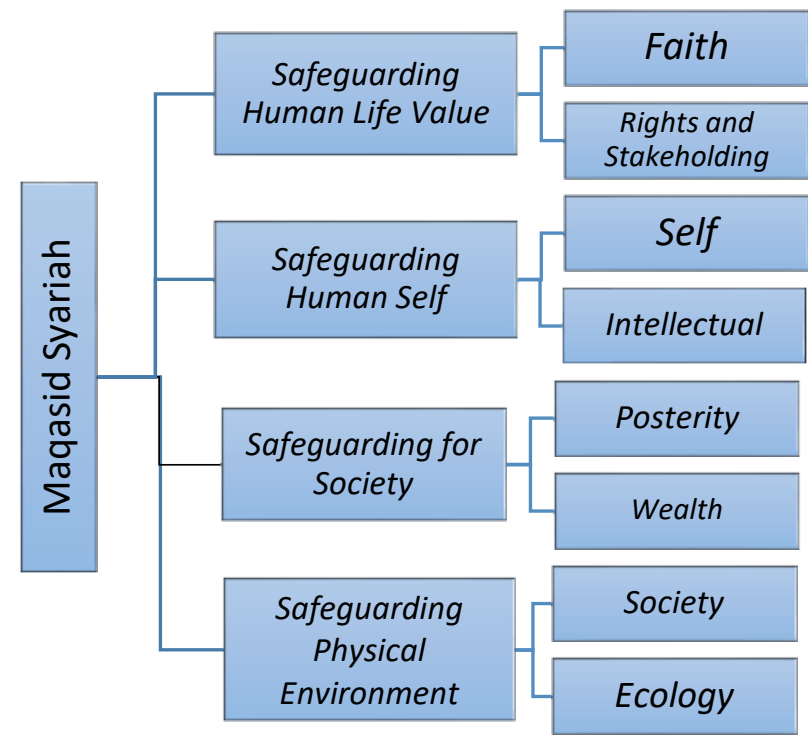

Sumber: Asutay dan Harningtyas (2015)

Konsep diatas sejalan dengan konsepsi umer Chapra (Bedoui dan Mansour, 2015) tentang arti penting etika dalam kegiatan ekonomi kedalam lima dimensi dan turunannya antara lain: pertama, dimensi pengayaan diri individu (enrichment of the human self dimension) yang mencakup (1) martabat, self-respect, dan persamaan sosial; (2) keadilan; (3) peningkatan spiritual dan moral; (4) perlindungan hidup dan kekayaan; (5) kebebasan; (6) pendidikan; (7) good governance; (8) pemenuhan kebutuhan; (9) pekerjaan; (10) distribusi pendapatan dan kekayaan yang layak; (11) pernikahan dan pengasuhan anak: (12) keluarga dan solidaritas sosial; (13) kebahagiaan dan kesehatan mental; dan (14) mengurangi kriminalitas

Kedua, dimensi pengayaan keyakinan atau aqidah (enrichment offaith dimension) mencakup (1) religious worldwide; (2) nilai-nilai; (3) motivasi yang tepat; (4) pendidikan; (5) keadilan, kebebasan, keamanan hidup, hak milik dan penghormatan, kejujuran, pemenuhan aspek sosial ekonomi dan tanggung jawab politik, kesabaran, 
hemat, kebijaksanaan, toleransi, saling peduli dan percaya; (6) penghapusan kemiskinan, pemenuhan seluruh kebutuhan, peluang kerja dan peluang bekerja secara mandiri; (7) distribusi yang layak; (8) integritas keluarga, solidaritas sosial, dan stabilitas politik; dan (9) good governance

Ketiga, dimensi pengayaan intelektual (enrichment of intellect dimension) meliputi (1) pertumbuhan yang layak; (2) pendidikan yang berkualitas tinggi pada harga yang memadai; (3) perpustakaan dan fasilitas riset; (4) kebebasan berfikir dan berekspresi; (5) penghargaan untuk kreatifitas; (6) keuangan; dan (7) perluasan pengetahuan dan tekhnologi.

Keempat, dimensi pengembangan kekayaan (development of wealth dimension) mencakup (1) pendidikan, riset, dan perbaikan teknologi dan manajemen; (2) hidup yang aman; (3) good governance; (4) kebebasan berusaha; (5) peluang kerja; (6) penghapusan kemiskinan, pemenuhan kebutuhan, dan distribusi yang merata; (7) solidaritas sosial dan mutual trust; (8) menabung dan investasi; dan (9) tingkat pertumbuhan yang optimal

Kelima, dimesi tambahan yang meliputi (1) pernikahan dan integritas keluarga; (2) solidaritas sosial; (3) pengembangan intelektualitas dan moral; (4) pemenuhan kebutuhan; (5) moral dan pendidikan yang mendunia; (6) lingkungan yang sehat; dan (7) terbebas dari konflik dan rasa tidak aman.

Maqasid syariah bersifat dinamis karena dapat berubah waktu. Sepeninggal Rasulullah SAW, ekspansi geografis wilayah Muslim di Timur dan Barat terintegrasi dengan budaya dan tardisi yang berbeda sehingga melahirkan madzab-madzab dalam pemikiran Islam (Mansour et al., 2015). Proses deduksi untuk menafsirkan dalil-dalil bervariasi menurut konteks sosial-ekonomi dan budaya. Maqasid syariah sesungguhnya tidak sesuai dengan visi maksimisasi profit bagi dunia bisnis. Sebaliknya, maqasid syariah mencakup perspketif yang lebih luas yang bertujuan untuk maksimalisasi keuntungan dengan upaya yang diarahkan pada memastikan kesehatan spiritual dan keadilan pada semua tingkat interaksi manusia.

\subsection{Metode Penelitian}

Penelitian ini merupakan penelitian evaluatif dengan melibatkan formulasi keuangan untuk menjawab masalah penelitian. Sumber data berupa data sekunder yaitu laporan tahunan yang telah divalidasi oleh Bank Indonesia dan Otoritas Jasa Keuangan (OJK) dan diperoleh dari website resmi bank syariah. Untuk mendapatkan skor kinerja sosial maka tujuan-tujuan diturunkan kedalam dimensi, elemen, dan pengukuran. Pengukuran dalam bentuk rasio dan pernyataan inilah yang digunakan untuk menilai kinerja sosial berbasis maqasid syariah.

Tabel-tabel berikut merupakan operasionalisasi model maqasid syariah empat tujuan yang dikembangkan oleh Abdel Majid Najjar.

\section{Tabel 1}

Operasionalisasi Maqasid Syariah Tujuan 1

Perlindungan Terhadap Nilai Kehidupan Manusia

\begin{tabular}{|c|c|c|c|}
\hline Dimensi (D) & Elemen (E) & Rasio/Pernyataan (R/P) & Sumber Data \\
\hline Faith (D1) & $\begin{array}{c}\text { Pembiayaan } \\
\text { Murah (E1) }\end{array}$ & $\begin{array}{c}\text { Mudharabah and Musyarakah } \\
\text { modes/Total Investment modes }\end{array}$ & Laporan Tahunan \\
\cline { 2 - 4 } & $\begin{array}{c}\text { Penghapusan } \\
\text { elemen negatif }\end{array}$ & Interest free income/total revenue & Laporan Tahunan \\
\hline
\end{tabular}




\begin{tabular}{|c|c|c|c|}
\hline & $\begin{array}{c}\text { akibat } \\
\text { ketidakadilan } \\
\text { (E2) }\end{array}$ & & \\
\hline & $\begin{array}{l}\text { Penekanan } \\
\text { filosofi dan nilai- }\end{array}$ & $\begin{array}{l}\text { Komitmen dalam operasional } \\
\text { dengan prinsip syariah }\end{array}$ & $\begin{array}{c}\text { Diisi } 0 \text { jika tidak } \\
\text { diungkapkan; dan } 1\end{array}$ \\
\hline & nilai (E3) & $\begin{array}{l}\text { Komitmen untuk melakukan } \\
\text { investasi yang sesuai prinsip } \\
\text { syariah }\end{array}$ & $\begin{array}{l}\text { jika diungkapkan } \\
\text { dalam laporan } \\
\text { tahunan }\end{array}$ \\
\hline & & $\begin{array}{l}\text { Komitmen pembiayaan pada } \\
\text { proyek-proyek sesuai prinsip } \\
\text { syariah }\end{array}$ & \\
\hline & $\begin{array}{l}\text { Aspek Produk } \\
\text { (E4) }\end{array}$ & $\begin{array}{l}\text { Produk mendapat persetujuan } \\
\text { Dewan Pengawas Syariah }\end{array}$ & \\
\hline & & Product Quality & \\
\hline & & Customer Complaints & \\
\hline Rights and & Karyawan (E5) & Pendidikan dan Pelatihan & Diisi 0 jika tidak \\
\hline $\begin{array}{l}\text { Stakeholdin } \\
\quad g \text { (D2) }\end{array}$ & & $\begin{array}{c}\text { Persamaan Kesempatan (Equal } \\
\text { Opportunities) }\end{array}$ & \\
\hline & & Keterlibatan Karyawan & dalam laporan \\
\hline & & Kesehatan dan Keselamatan Kerja & tahunan \\
\hline & & Lingkungan Kerja & \\
\hline & Corporate & Kepatuhan syariah & \\
\hline & Governance (E6) & Struktur Kepemilikan & \\
\hline & & $\begin{array}{c}\text { Pernyataan tentang aktifitas yang } \\
\text { tidak diperbolehkan }\end{array}$ & \\
\hline & & $\begin{array}{c}\text { Jumlah Anggota DPS tidak kurang } \\
\text { dari } 2\end{array}$ & \\
\hline & & Kebijakan anti korupsi & \\
\hline
\end{tabular}

Sumber: Asutay dan Harningtyas (2015); Sofyani et al. (2012)

Maqasid syariah pada tujuan 1 (01) merupakan perlindungan terhadap nilai kehidupan manusia. Tujuan ini dibagi kedalam 2 dimensi yaitu faith dan rights and stakeholding. Dimensi 1 (D1) dibagi kedalam 4 elemen yaitu E1-E4, sedangkan dimensi 2 (D2) dibagi kedalam 2 elemen (E5-E6). Setiap elemen diukur melalui indikatorindikator baik rasio maupun pernyataan-pernyataan yang diungkapkan dalam laporan tahunan bank syariah. Proporsi pernyataan lebih tinggi dibandingkan rasio dalam penelitian ini. Tujuan ini lebih menekankan pada komitmen bank syariah untuk menjalankan prinsip-prinsip syariah Islam yang menjamin konsumen telah mendapatkan produk yang sesuai dengan prinsip bank syariah. Dari 18 pengukuran terdapat 2 rasio dan 16 pernyataan. Skor 1 jika diungkapkan dan 0 jika tidak diungkapkan dalam laporan tahunan masing-masing bank. Total skor pada tujuan 1 merupakan penjumlahan dari masing-masing nilai pada rasio dan pernyataan.

Tabel 2

Operasionalisasi Maqasid Syariah Tujuan 2

Perlindungan Terhadap Nilai Diri Manusia

\begin{tabular}{|l|l|l|l|}
\hline $\begin{array}{l}\text { Dimensi } \\
\text { (D) }\end{array}$ & $\begin{array}{l}\text { Elemen } \\
\text { (E) }\end{array}$ & $\begin{array}{l}\text { Rasio } \\
\text { (R) }\end{array}$ & Sumber Data \\
\hline Self (D3) & $\begin{array}{l}\text { Investasi pada } \\
\text { sektor riil yang } \\
\text { vital (E7) }\end{array}$ & $\begin{array}{l}\text { Investment in real economic } \\
\text { sector/total investment }\end{array}$ & $\begin{array}{l}\text { Laporan } \\
\text { Tahunan }\end{array}$ \\
\hline
\end{tabular}




\begin{tabular}{|l|l|l|l|}
\hline $\begin{array}{l}\text { Intelektu } \\
\text { al (D4) }\end{array}$ & $\begin{array}{l}\text { Kemajuan ilmu } \\
\text { pengetahuan } \\
\text { melalui } \\
\text { beasiswa } \\
\text { pendidikan dan } \\
\text { riset (E8) }\end{array}$ & $\begin{array}{l}\text { Scholarship and Research } \\
\text { Expense/Total Expenses }\end{array}$ & \\
& $\begin{array}{l}\text { Penerapan } \\
\text { ketrampilan } \\
\text { baru dan } \\
\text { perbaikan } \\
\text { melalui } \\
\text { pelatihan (E9) }\end{array}$ & Training expense/total \\
expenses & \\
& $\begin{array}{l}\text { Menciptakan } \\
\text { kepedulian } \\
\text { terhadap bank } \\
\text { syariah melalui } \\
\text { publikasi (E10) }\end{array}$ & Publicity & \\
& expenses & \\
& & \\
& & \\
\end{tabular}

Sumber: Asutay dan Harningtyas (2015); Sofyani et al. (2012)

Tujuan 2 (02) merupakan perlindungan terhadap nilai diri manusia yang dibagi kedalam 2 dimensi yaitu self atau nafs (D3) dan intelektual (D4). Dimensi self dapat diketahui dari elemen 7 (E7) yaitu tingkat investasi pada sektor riil yang vital. Dimensi intelektual dilihat dari beberapa elemen yaitu kemajuan ilmu pengetahuan melalui beasiswa pendidikan (E8), penerapan ketrampilan baru dan perbaikan melalui pelatihan (E9), dan menciptakan kepedulian terhadap bank syaraiah melalui publikasi (E10). Masing-masing elemen diukur melalui rasio-rasio keuangan yang menggambarkan seberapa besar tingkat pengeluaran bank syariah dalam mencapai tujuan perlindungan terhadap diri manusia pada bidang investasi sektor riil, beasiswa pendidikan dan riset, pelatihan, dan publikasi. Tinggi rendahnya tingkat pengeluaran bidang tersebut menunjukkan tingkat komitmen bank syariah dalam meningkatkan kualitas sumber daya manusia. Total skor untuk tujuan 2 diperoleh dari penjumlahan pada seluruh rasio.

Tabel 3

Operasionalisasi Maqasid Syariah Tujuan 3

Perlindungan Terhadap Masyarakat

\begin{tabular}{|c|c|c|c|}
\hline Dimensi (D) & Elemen (E) & Rasio/Pernyataan (R/P) & Sumber Data \\
\hline \multirow[t]{4}{*}{$\begin{array}{l}\text { Posterity } \\
\text { (D5) }\end{array}$} & $\begin{array}{l}\text { Kewajiban Qard } \\
\text { dan donasi (E11) }\end{array}$ & $\begin{array}{l}\text { Qard and Donation/(total revenue- } \\
\text { Zakat\&Tax) }\end{array}$ & \multirow[t]{4}{*}{$\begin{array}{l}\text { Laporan } \\
\text { Tahunan }\end{array}$} \\
\hline & $\begin{array}{l}\text { Kewajiban } \\
\text { memakmurkan } \\
\text { karyawan (E12) }\end{array}$ & $\begin{array}{l}\text { Employee Expense/(total revenue- } \\
\text { Zakat\&Tax) }\end{array}$ & \\
\hline & $\begin{array}{l}\text { Kewajibah } \\
\text { memakmurkan } \\
\text { pemegang saham } \\
\text { (E13) }\end{array}$ & $\begin{array}{l}\text { Dividen to shareholder/(total revenue- } \\
\text { Zakat\&Tax) }\end{array}$ & \\
\hline & Profit (E14) & Net Profit/(total revenue-Zakat\&Tax) & \\
\hline \multirow[t]{3}{*}{ Social (D6) } & $\begin{array}{l}\text { Zakat, Amal, dan } \\
\text { Pinjaman }\end{array}$ & $\begin{array}{l}\text { Tanggung jawab bank dalam membayar } \\
\text { zakat }\end{array}$ & \multirow{3}{*}{$\begin{array}{lll}\text { Diisi } & 0 & \text { jika } \\
\text { tidak } & \\
\text { diungkapkan; } \\
\text { dan } 1 \text { jika }\end{array}$} \\
\hline & Kebajikan (E15) & Jumlah zakat yang dibayarkan bank & \\
\hline & & Jumlah zakat yang tidak didistribusikan & \\
\hline
\end{tabular}




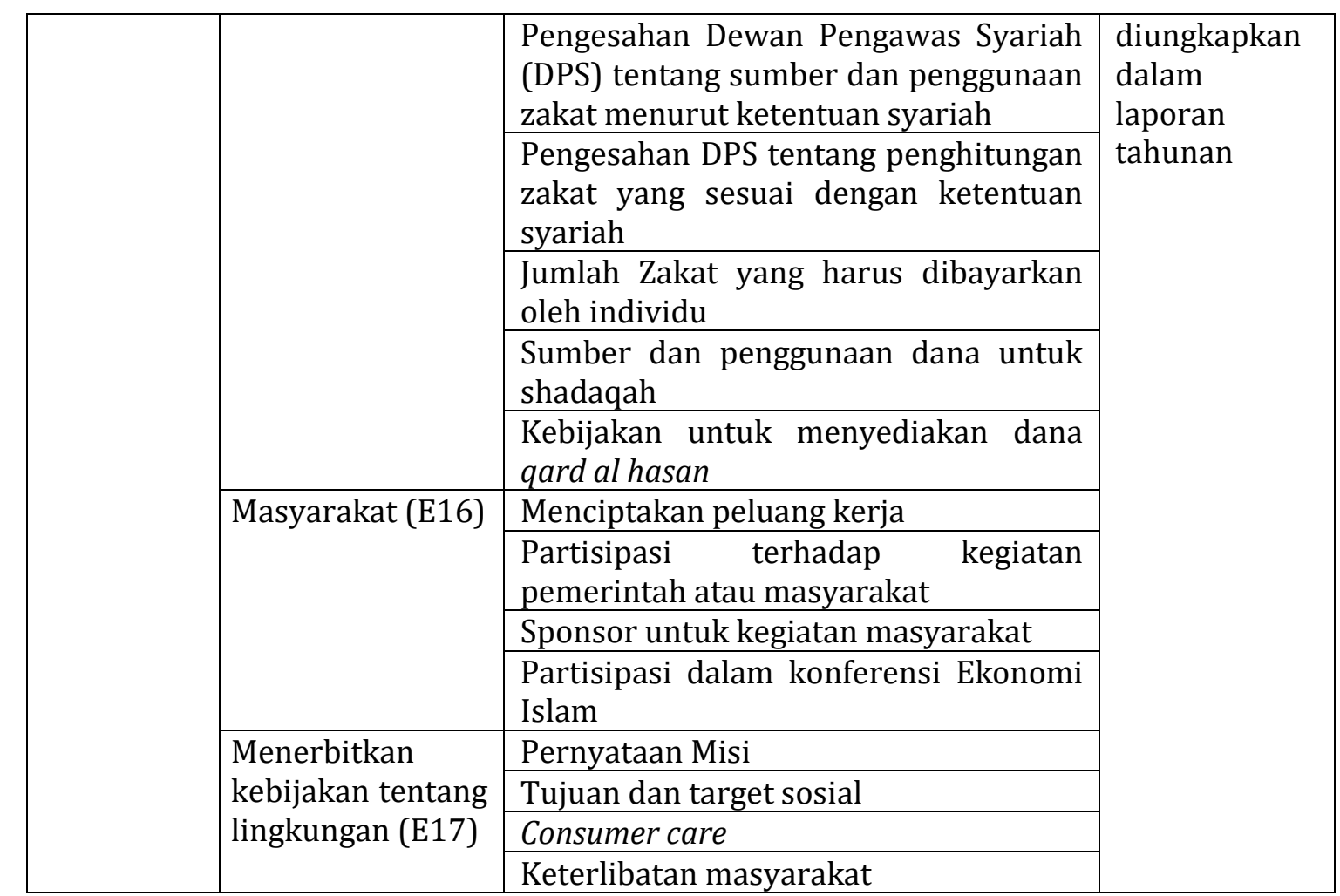

Sumber: Asutay dan Harningtyas (2015); Sofyani et al. (2012)

Tujuan 3 (O3) meliputi 2 dimensi yaitu posterity (D5) dan sosial (D6). Dimensi 5 mencakup 3 elemen yaitu elemen 11 (E11) sampai dengan elemen 14 (E14) yang antara lain kewajiban qard dan donasi, kewajiban memakmurkan karyawan, kewajiban memakmurkan pemegang saham, dan tujuan pencapaian laba (profit). Sedangkan dimensi 6 diukur melalui elemen 15 (E15) sampai dengan elemen 17 (E17) yang meliputi kegiatan zakat, amal, pinjaman kebajikan, masyarakat, dan menrbitkan kebijakan tentang lingkungan. Masing-masing elemen dinilai berdasarkan beberapa rasio dan pernyataan-pernyataan yang relevan dengan pencapaian tujuan perlindungan terhadap masyarakat baik yang terlibat langsung dengan kegiatan bank syariah maupun yang tidak langsung.

\section{Tabel 4}

Operasionalisasi Maqasid Syariah Tujuan 4

Perlindungan Terhadap Lingkungan Fisik

\begin{tabular}{|c|c|c|c|}
\hline $\begin{array}{l}\text { Dimensi } \\
\text { (D) }\end{array}$ & $\begin{array}{l}\text { Elemen } \\
\text { (E) }\end{array}$ & $\begin{array}{l}\text { Rasio/Pernyataan } \\
\text { (R/P) }\end{array}$ & Sumber Data \\
\hline \multirow[t]{5}{*}{$\begin{array}{l}\text { Wealth } \\
\text { (D7) }\end{array}$} & Fair Return (E18) & $\begin{array}{l}\text { Profit Equalization } \\
\text { Reserves/Net Investment } \\
\text { Income }\end{array}$ & \multirow[t]{5}{*}{$\begin{array}{l}\text { Laporan } \\
\text { Tahunan }\end{array}$} \\
\hline & $\begin{array}{l}\text { Struktur } \\
\text { Pendanaan (E19) }\end{array}$ & Capital to Risk Assets ratio & \\
\hline & $\begin{array}{l}\text { Loan Loss Ratio } \\
\text { (E20) }\end{array}$ & $\begin{array}{l}\text { Loan Loss } \\
\text { Provision/operating } \\
\text { revenue }\end{array}$ & \\
\hline & $\begin{array}{l}\text { Operational } \\
\text { efficiency (E21) }\end{array}$ & $\begin{array}{l}\text { Operating } \\
\text { expense/operating } \\
\text { Revenue }\end{array}$ & \\
\hline & $\begin{array}{l}\text { Earning Ability } \\
\text { (E22) }\end{array}$ & Net Income/total assets & \\
\hline
\end{tabular}




\begin{tabular}{|c|c|c|c|}
\hline & \multirow[t]{3}{*}{ Liquidity (E23) } & Net Income/total equities & \\
\hline & & Loan/Total Assets & \\
\hline & & Deposits/total Assets & \\
\hline \multirow[t]{9}{*}{$\begin{array}{l}\text { Ecology } \\
\text { (D8) }\end{array}$} & \multirow[t]{8}{*}{$\begin{array}{l}\text { Environment } \\
\text { Indicators (E24) }\end{array}$} & $\begin{array}{l}\text { Mission } \\
\text { statement/statement of } \\
\text { environment policy }\end{array}$ & \multirow{8}{*}{$\begin{array}{l}\text { Diisi } 0 \text { jika } \\
\text { tidak } \\
\text { diungkapka } \\
\text { n; dan } 1 \text { jika } \\
\text { diungkapka } \\
\text { n dalam } \\
\text { laporan } \\
\text { tahunan }\end{array}$} \\
\hline & & $\begin{array}{l}\text { Environment target and } \\
\text { objectives }\end{array}$ & \\
\hline & & Environment protection & \\
\hline & & $\begin{array}{l}\text { View on environmnet } \\
\text { issues }\end{array}$ & \\
\hline & & $\begin{array}{l}\text { Environment } \\
\text { management system }\end{array}$ & \\
\hline & & Energy saving & \\
\hline & & $\begin{array}{l}\text { Environment indicator } \\
\text { and target }\end{array}$ & \\
\hline & & Carbon emission Report & \\
\hline & $\begin{array}{l}\text { Contribution to } \\
\text { environment } \\
\text { (E25) }\end{array}$ & $\begin{array}{l}\text { Ecological donation/qard } \\
\text { and total donation }\end{array}$ & $\begin{array}{l}\text { Laporan } \\
\text { Tahunan }\end{array}$ \\
\hline
\end{tabular}

Sumber: Asutay dan Harningtyas (2015); Sofyani et al. (2012)

Tujuan 4 (04) adalah tujuan perlindungan terhadap lingkungan fisik (safeguarding physical environment objective) yang meliputi dimensi wealth (D7) dan ecology (D8). Dimensi 7 diukur dari elemen 18 (E18) sampai dengan elemen 23 (E23) meliputi fair return, struktur pendanaan, loan loss provision, operational efficiency, earning ability, dan likuiditas. Sedangkan dimensi 8 dinilai melalui elemen 24 (E24) dan elemen 25 (E25) yaitu indikator lingkungan (environment indicators) dan kontribusi terhadap lingkungan (contribution to environment). Masing-masing elemen diukur dengan rasio dan pernyataan yang menggambarkan pencapaian tujuan perlindungan terhadap lingkungan fisik.

Skor total dihitung dengan menjumlahkan seluruh skor pada tujuan 1 sampai dengan tujuan 4. Adapun bank yang diteliti adalah bank umum syariah hasil konversi yaitu Bank Syariah Mandiri, Bank Mega Syariah Indonesia, Bank Panin Syariah, Bank Central Asia Syariah, dan Bank Victoria Syariah untuk periode 2014-2017.

\section{HASIL DAN PEMBAHASAN}

\subsection{Hasil Analisis Data}

Jalur operasionalisasi penilaian kinerja sosial berbasis maqasid syariah menurut Abdel Majid Najjar terdiri dari 4 tujuan (01-04) dengan 8 dimensi (D1-D8) dan rasio-rasio serta pernyataan-pernyataan sebagai alat ukurnya. Model tersebut mencakup aspekaspek yang lebih luas tetapi spesifik pada masing-masing tujuan. Orientasi sosial ditujukan pada berbagai aspek yang berkaitan dengan terbentuknya ketahanan keuangan bank syariah, pengembangan sumber daya manusia bank syariah dan masyarakat, serta perhatian dan komitmen terhadap lingkungan sosial dan fisik.

Adapun berdasarkan hasil penilaian terhadap 5 bank syariah hasil konversi diperoleh nilai untuk masing-masing tujuan pada tabel-tabel sebagai berikut: 


\section{Tabel 5}

Hasil Penilaian Tujuan 1

Perlindungan Terhadap Nilai Kehidupan Manusia

\begin{tabular}{|l|c|c|c|c|}
\hline \multirow{2}{*}{ Nama Bank } & \multicolumn{4}{|c|}{ Tahun } \\
\cline { 2 - 5 } & 2014 & 2015 & 2016 & 2017 \\
\hline Bank Syariah Mandiri & 16,36922 & 16,45566 & 16,51041 & 16,58750 \\
\hline $\begin{array}{l}\text { Bank Mega Syariah } \\
\text { Indonesia }\end{array}$ & 16,21165 & 16,45403 & 16,48922 & 16,23871 \\
\hline Bank Panin Syariah & 16,60628 & 17,63609 & 17,47886 & 17,51903 \\
\hline Bank Central Asia Syariah & 16,88183 & 16,81750 & 16,86713 & 16,89723 \\
\hline Bank Victoria Syariah & 17,01293 & 17,16581 & 17,37523 & 16,76085 \\
\hline
\end{tabular}

Tabel 5 menunjukkan skor dari masing-masing bank syariah dalam pencapaian tujuan 1 yaitu perlindungan terhadap nilai kehidupan manusia dari tahun 2014-2017. Pada 2014, skor tertinggi sebesar 17,01293 dicapai oleh Bank Victoria Syariah dan skor terendah sebesar 16,21165 pada Bank Mega Syariah Indonesia. Pada 2015, skor tertinggi sebesar 17,63609 dicapai oleh Bank Panin Syariah dan skor terendah sebesar 16,45403 pada Bank Mega Syariah Indonesia. Pada 2016, skor tertinggi sebesar 17,47886 dicapai oleh Bank Panin Syariah dan skor terendah sebesar 16,48922 pada Bank Mega Syariah Indonesia. Sedangkan pada 2017, skor tertinggi kembali dicapai oleh Bank Panin Syariah sebesar 17,51903 dan skor terendah juga pada Bank Mega Syariah Indonesia sebesar 16,23871.

\section{Tabel 6}

Hasil Penilaian Tujuan 2

Perlindungan Terhadap Nilai Diri Manusia

\begin{tabular}{|l|c|c|c|c|}
\hline \multirow{2}{*}{ Nama Bank } & \multicolumn{4}{|c|}{ Tahun } \\
\cline { 2 - 5 } & 2014 & 2015 & 2016 & 2017 \\
\hline Bank Syariah Mandiri & 0,02083 & 0,03232 & 0,01643 & 0,02345 \\
\hline $\begin{array}{l}\text { Bank Mega Syariah } \\
\text { Indonesia }\end{array}$ & 0,00462 & 0,00211 & 0,00522 & 0,00591 \\
\hline Bank Panin Syariah & 0,01418 & 0,00852 & 0,00787 & 0,00750 \\
\hline Bank Central Asia Syariah & 0,02752 & 0,03403 & 0,02253 & 0,07216 \\
\hline Bank Victoria Syariah & 0,02810 & 0,01911 & 0,01466 & 0,02022 \\
\hline
\end{tabular}

Tabel 6 menunjukkan skor dari masing-masing bank syariah dalam pencapaian tujuan 2 yaitu perlindungan terhadap nilai diri manusia dari tahun 2014-2017. Pada 2014, skor tertinggi sebesar 0,02810 dicapai oleh Bank Victoria Syariah dan skor terendah sebesar 0,00462 pada Bank Mega Syariah Indonesia. Pada 2015, skor tertinggi sebesar 0,03403 dicapai oleh Bank Central Asia Syariah dan skor terendah sebesar 0,00211 pada Bank Mega Syariah Indonesia. Pada 2016, skor tertinggi sebesar 0,02253 dicapai oleh Bank Central Asia Syariah dan skor terendah sebesar 0,00522 pada Bank Mega Syariah Indonesia. Sedangkan pada 2017, skor tertinggi kembali dicapai oleh Bank Central Asia Syariah sebesar 0,07216 dan skor terendah juga pada Bank Mega Syariah Indonesia sebesar 0,00591. 
Tabel 7

Hasil Penilaian Tujuan 3

Perlindungan Terhadap Masyarakat

\begin{tabular}{|l|c|c|c|c|}
\hline \multirow{2}{*}{ Nama Bank } & \multicolumn{4}{|c|}{ Tahun } \\
\cline { 2 - 5 } & 2014 & 2015 & 2016 & 2017 \\
\hline Bank Syariah Mandiri & 14,82383 & 14,23991 & 14,22834 & 14,22649 \\
\hline $\begin{array}{l}\text { Bank Mega Syariah } \\
\text { Indonesia }\end{array}$ & 15,25360 & 15,17530 & 15,16208 & 16,75942 \\
\hline Bank Panin Syariah & 14,21264 & 14,17123 & 14,14097 & 13,00414 \\
\hline Bank Central Asia Syariah & 14,63293 & 14,50700 & 14,53975 & 14,56479 \\
\hline Bank Victoria Syariah & 14,08035 & 14,01533 & 14,07052 & 14,19080 \\
\hline
\end{tabular}

Tabel 7 menunjukkan skor dari masing-masing bank syariah dalam pencapaian tujuan 3 yaitu perlindungan terhadap masyarakat dari tahun 2014-2017. Pada 2014, skor tertinggi sebesar 15,25360 dicapai oleh Bank Mega Syariah Indonesia dan skor terendah sebesar 14,08035 pada Bank Victoria Indonesia. Pada 2015, skor tertinggi sebesar 15,17530 dicapai oleh Bank Mega Syariah Indonesia dan skor terendah sebesar 14,01533 pada Bank Victoria Syariah. Pada 2016, skor tertinggi sebesar 15,16208 dicapai oleh Bank Mega Syariah Indonesia dan skor terendah sebesar 14,07052 pada Bank Victoria Syariah. Sedangkan pada 2017, skor tertinggi kembali dicapai oleh Bank Mega Syariah Indonesia sebesar 16,75942 dan skor terendah pada Bank Panin Syariah sebesar 13,00414.

\section{Tabel 8}

Hasil Penilaian Tujuan 4

Perlindungan Terhadap Lingkungan Fisik

\begin{tabular}{|l|r|r|r|r|}
\hline \multirow{2}{*}{ Nama Bank } & \multicolumn{4}{|c|}{ Tahun } \\
\cline { 2 - 5 } & 2014 & \multicolumn{1}{c|}{2015} & \multicolumn{1}{c|}{2016} & \multicolumn{1}{c|}{2017} \\
\hline Bank Syariah Mandiri Syariah & 11,10768 & 9,83562 & 10,14185 & 10,09673 \\
\hline $\begin{array}{l}\text { Bank Mega } \\
\text { Indonesia }\end{array}$ & & 10,02105 & 10,04356 & 9,43026 \\
\hline Bank Panin Syariah & 3,65110 & 3,66998 & 8,56661 & 2,70344 \\
\hline Bank Central Asia Syariah & 8,95546 & 9,16796 & 9,21735 & 9,01876 \\
\hline Bank Victoria Syariah & 3,06021 & 2,90945 & 3,00603 & 2,56745 \\
\hline
\end{tabular}

Tabel 8 menunjukkan skor dari masing-masing bank syariah dalam pencapaian tujuan 4 yaitu perlindungan terhadap lingkungan fisik dari tahun 2014-2017. Pada 2014, skor tertinggi sebesar 11,10768 dicapai oleh Bank Syariah mandiri dan skor terendah sebesar 3,06021 pada Bank Victoria Indonesia. Pada 2015, skor tertinggi sebesar 10,02105 dicapai oleh Bank Mega Syariah Indonesia dan skor terendah sebesar 2,90945 pada Bank Victoria Syariah. Pada 2016, skor tertinggi sebesar 10,14185 dicapai oleh Bank Syariah mandiri dan skor terendah sebesar 3,00603 pada Bank Victoria Syariah. Sedangkan pada 2017, skor tertinggi kembali dicapai oleh Bank Syariah mandiri sebesar 10,09673 dan skor terendah pada juga pada Bank Victoria Syariah sebesar 2,56745. 


\section{Tabel 9}

Hasil Penilaian Kumulatif

Kinerja Sosial Berbasis Maqasid Syariah

\begin{tabular}{|l|c|c|c|c|}
\hline \multirow{2}{*}{ Nama Bank } & \multicolumn{4}{|c|}{ Tahun } \\
\cline { 2 - 5 } & 2014 & 2015 & 2016 & 2017 \\
\hline Bank Syariah Mandiri & 42,32156 & 40,56351 & 40,89703 & 40,93420 \\
\hline $\begin{array}{l}\text { Bank Mega Syariah } \\
\text { Indonesia }\end{array}$ & 41,25236 & 41,65249 & 41,70008 & 42,43432 \\
\hline Bank Panin Syariah & 34,48420 & 35,48572 & 40,20431 & 33,23411 \\
\hline Bank Central Asia Syariah & 40,49774 & 40,52649 & 40,64676 & 40,55294 \\
\hline Bank Victoria Syariah & 34,18159 & 34,10970 & 34,46644 & 33,53932 \\
\hline
\end{tabular}

Tabel 9 menunjukkan skor total dari masing-masing bank syariah dalam penilaian kinerja sosial berbasis maqasid syariah dari tahun 2014-2017. Pada 2014, skor tertinggi sebesar 42,32156 dicapai oleh Bank Syariah mandiri dan skor terendah sebesar 34,18159 pada Bank Victoria Indonesia. Pada 2015, skor tertinggi sebesar 41,65249 dicapai oleh Bank Mega Syariah Indonesia dan skor terendah sebesar 34,10970 pada Bank Victoria Syariah. Pada 2016, skor tertinggi sebesar 41,70008 dicapai oleh Bank Mega Syariah Indonesia dan skor terendah sebesar 34,46644 pada Bank Victoria Syariah. Sedangkan pada 2017, skor tertinggi kembali dicapai oleh Bank Mega Syariah Indonesia sebesar 42,43432 dan skor terendah pada juga pada Bank Panin Syariah sebesar 33,23411.

\subsection{Pembahasan}

Bank syariah yang mencapai skor tinggi pada tujuan 1 menunjukkan komitmen yang tinggi pada upaya pembiayaan murah melalui pembiayaan mudharabah dan musyarakah, dan penghapusan elemen negatif akibat ketidakadilan dengan meningkatkan penerimaan pada pendapatan bebas bunga. Selain itu juga penekanan pada komitmen untuk menjalankan filosofi nilai-nilai yang sesuai dengan prinsip syariah baik pada operasional, investasi, pembiayaan, dan layanan terhadap konsumen. Sedangkan pada karyawan, bank syariah berkomitmen untuk menjalankan pendidikan dan pelatihan, memberikan persamaan kesempatan, melibatkan karyawan, memperhatikan kesehatan dan keselamatan kerja, dan lingkungan kerja. Upaya mewujudkan corporate governance dilakukan dalam bentuk komitmen pada kepatuhan syariah, struktur kepemilikan, aktifitas yang dilarang, dan kebijakan anti korupsi.

Tinggi rendahnya skor pencapaian tujuan 2 ditentukan oleh realisasi bank dalam alokasi investasi pada sektor ekonomi riil dan berbagai pengeluaran yang berkaitan dengan kemajuan ilmu pengetahuan, peningkatan ketrampilan baru, dan kepedulian terhadap bank syariah. Alokasi pada aspek intelektual meliputi besaran pengeluaran pada beasiswa pendidikan, riset, pelatihan, dan publikasi.

Komitmen untuk mencapai tujuan 3 dapat dilihat dari alokasi bank syariah dalam menjalankan kewajiban qard dan donasi berdasarkan tingkat pendapatan setelah zakat dan pajak, pengeluaran gaji karyawan, pembagian dividen, dan tingkat perbandingan lava yang diperoleh dengan laba bersih setelah zakat dan pajak. Sedangkan pada dimensi sosial berkaitan dengan komitmen untuk melaporkan jumlah zakat baik yang didistribusikan maupun yang tidak. Pengesahan Dewan Pengawas Syariah (DPS) merupakan faktor penting dalam memberikan pertimbangan terhadap 
tanggung jawab penghimpunan dan penyaluran zakat. Bank syariah juga memiliki tanggung jawab dalam kebijakan menyediakan dana kebajikan (qard al hasan). Menciptakan peluang kerja, berpartisipasi dalam kegiatan pemerintah atau masyarakat, sponsor untuk kegiatan masyarakat, dan berpartisipasi dalam konferensi ekonomi Islam merupakan kontribusi bank syariah terhadap kepentingan masyarakat. Sedangkan dalam hal lingkungan harus pula dinyatakan melalui pernyataan misi, tujuan dan target sosial, consumer care, dan keterlibatan masyarakat.

Tanggung jawab sosial bank syariah pada tujuan 4 meliputi bagaimana mengelola harta (wealth) yang sesuai denga prinsip syariah melalui fair return, proporsi modal terhadap aset berisiko, pencadangan kemungkinan pinjaman bermasalah, efisiensi biaya, kemampuan menghasilkan pendapatan, dan pengelolaan likuiditas baik pada manajemen laba bersih, pembiayaan, dana pihak ketiga. Dimensi ekologi ditekankan pada komitmen yang dinyatakan dalam misi, target, tujuan, dan proteksi terhadap lingkungan. Selain itu juga pada pandangan bank syariah terhadap isu-isu lingkungan, sistem manajemen lingkungan, penghematan energy, indikator dan target lingkungan, laporan emisi karbon, dan donasi pada aspek ekologi yang bersumber dari dana qard dan donasi. Meskipun bank syariah tidak terlibat dalam kerusakan lingkungan namun komitmen ini diperlukan dalam rangka menciptakan lingkungan yang sehat bagi masyarakat sebagai salah satu bagian amal kebajikan yang sesuai dengan tujuan syariah.

\section{PENUTUP}

Maqasid syariah dalam sistem keuangan Islam merupakan cita-cita atau tujuan syariah yang berkaitan dengan transaksi dan kegiatan keuangan menurut standar, kriteria, dan nilai-nilai syariat Islam untuk memecahkan masalah umat manusia sehingga tercapai kemaslahatan. Kinerja sosial bank syariah berbasis maqasid syariah memperhatikan berbagai aspek yang berkaitan dengan keseimbangan antara kegiatan operasional, kepentingan stakeholder internal, kepentingan masyarakat, dan lingkungan dengan landasan nilai-nilai Islam.

Penelitian ini mengembangkan penilaian kinerja sosial berbasis maqasid syariah berdasarkan 4 tujuan, 8 dimensi, dan 25 elemen. Dari masing-masing elemen diukur kedalam 19 rasio dan 46 pernyataan. Hasil diatas menunjukkan perubahan tren pencapaian skor pada masing-masing tujuan. Bank Panin Syariah mencapai skor tertinggi pada tujuan perlindungan terhadap nilai kehidupan manusia (tujuan 1) selama periode 2015-2017. Bank Central Asia Syariah mencapai skor tertinggi pada tujuan perlindungan terhadap nilai diri manusia (tujuan 2) selama periode 2015-2017. Bank Mega Syariah Indonesia mencapai skor tertinggi pada tujuan perlindungan terhadap masyarakat (tujuan 3) selama periode 2014-2017. Bank Syariah Mandiri mencapai skor tertinggi pada tujuan perlindungan terhadap lingkungan fisik (tujuan 4) untuk periode 2014, 2016, dan 2017. Total skor tertinggi untuk keseluruhan tujuan dicapai oleh Bank Mega Syariah Indonesia selama periode 2015-2017. 


\section{DAFTAR PUSTAKA}

Abu Bakar, F., dan Md. Yusof, M.A., 2015, Islamic Concept of Corporate Social Responsibility (CSR) from the Perspective of CSR Players at Bank Islam Malaysia Berhad, International Conference on Accounting Studies (ICAS) 17-20 Agustus 2015, Johor Bahru, Johor, Malaysia (Proceeding): 120-127

Aliyu, S., 2014, Sustainable Islamic Banking: A Conceptual Framework for Non-Interest Banks in Nigeria, International Journal of Economics, Management, and Accounting 22, No. 1:33-62

Asutay, M. dam Harningtyas, A. F., 2015, Developing Maqasid al-Shari'ah Index to Evaluate Social Performance of Islamic Banks: A Conceptual and Empirical Attempt, International Journal of Islamic Economic and Finance Studies, Year 1, Volume 1, Number 1: 5-61

Bedoui, H. E. dan Mansour, W., 2015, Performance and Maqasid al-Shari'ah's Pentagon Shaped Ethical Measurement, Journal of Science and Engineering Ethics, 21(3): 555-576

Chapra, M. U., 2009, The Global Financial Crisis Can Islamic Finance Help?, Insight 01: 4: 27-38

Dusuki, A. W., 2008, Understanding the Objectives of Islamic Banking: a Survey of Stakeholders' Perspectives, International Journal of Islamic and Middle Eastern Finance and Management, Vol. 1, No. 2:132-148

Hurayra, M. A., 2015, Achievement of Maqsid-al-Shari'ah in Islamic Banking: An Evaluation of Islami Bank Bangladesh Limited, Global Journal of Computer Science and Technology, Volume XV Issue I, Version 1: 9-15

Laldin, M. A. and Furqani, H., 2013, Developing Islamic finance in the framework of maqasid al-Shari'ah: Understanding the ends (maqasid) and the means (wasa'il), International Journal of Islamic and Middle Eastern Finance and Management Vol. 6 No. 4, 2013: 278-289

Mansour, W., Jedidia, K. B., and Majdoub, J., 2015, How Ethical Is Islamic Banking in The Light of The Objectives of Islamic Law?, Journal of Religious Ethics, 43, 1: 51-77

Mohammed, M. O, Tarique, K. M., and Islam, R., 2015, Measuring the performance of Islamic banks using maqāsid-based model, Intellectual Discourse, 23: 401-424

Elahi, M. E, 2010, The Objectives and Intens of Islamic Shari'ah as a Paradigm of Development Strategies and Policies, IIUC Studies, Vol. 7, Desember: 321-336

Bank Indonesia, 2009, Peraturan Bank Indonesia PBI Nomor 11/15/PBI/2009

Bank Indonesia, 2009, Peraturan Bank Indonesia PBI Nomor 11/03/PBI/2009

Bank Indonesia, 2009, Peraturan Bank Indonesia PBI Nomor 11/10/PBI/2009

Siwar, C., and Hossain, M. T., 2009, an Analysis of Islamic CSR Concept and the Opinions of Malaysian Managers, Management of Environmental Quality: An International Journal, Vol. 20, No. 3: 290-298

Sofyani, H., Ulum, I., Syam, D., dan Wahyuni, S., 2012, Islamic Social Reporting Sebagai Model Pengukuran Kinerja Sosial Perbankan Syariah (Studi Komparasi Indonesia dan Malaysia), Jurnal Dinamika Akuntansi, Vol. 4, No 1: 36-46 